\title{
Ethnomedicinal value, phytochemical composition and bioactivity of Butea monosperma (Lam.) Taub.
}

\author{
Fakhruddin Ali Ahmed* and Humayun Kabir \\ Department of Botany, Jahangirnagar University, Savar, Dhaka-1342, Bangladesh
}

\begin{abstract}
Ethnomedicinal study on Butea monosperma (Lam.) Taub. revealed that native people of Netrokona district extensively use flower, bark and leaves of the plant to treat different kinds of diseases. People of the studied area used the plant to treat goiter, diabetes, painful menstruation, body swellings, intestinal worms, urinary stone, leucorrhoea and chronic fever. Application of root powder mixed with honey as an antidote for snake bite was recorded for the first time. Phytochemical screening of the methanolic extracts of flowers, leaves and stem of this plant showed the presence of carbohydrate, flavonoid, glycosides, saponins, terpenoids and steroids. Through qualitative assessment, flower was found to be rich in flavonoids compared to leaf and stem. Leaf extract of $B$. monosperma showed relatively higher cytotoxicity than flower and stem extracts. The highest free radical scavenging activity was observed in flower sample (73.49\%) and the lowest in leaf sample $(48.17 \%)$. The results of the present study may be a proof of a scientific basis for the use of B. monosperma in traditional medicine.
\end{abstract}

Key words: Butea monosperma, phytochemical composition, bioactivity, TPC.

\section{INTRODUCTION}

Bangladesh is a home to a number of tribes or indigenous communities. Latest ethnographic research suggests that the number of tribes within the country approximates more than 100 instead of the previously estimated about a dozen tribes (Murmu, 2009). Traditional medicine practices and ethnobotanical information play an important role in the scientific research, particularly when the literature and fieldwork data have been properly evaluated. The knowledge of ethnobotanical use of plants often results in the discovery of new biologically active molecules (Gurib-Fakim, 2006). According to WHO, medicinal plants would be the best source to obtain a variety of drugs. Systematic screening of folk medicines and plants may result in the discovery of novel effective compounds (Tomoko et al., 2002).

There are around 5,000 angiosperms distributed among 200 families in Bangladesh and approximately, 500 of these are being used in the traditional medicines for the treatment of different types of diseases (Rashid et al., 2014). Among them, Butea monosperma (Family: Fabaceae), popularly known as 'palas' in Bengali, has been found to display a wide variety of biological activities. It is a moderate sized deciduous tree and widely distributed throughout Bangladesh, Myanmar, Ceylon and India. The plant is traditionally reported to possess astringent, bitter, alterative, aphrodisiac, anthelmintic, antimicrobial,

\footnotetext{
* Corresponding author: faahmed_ju@yahoo.com
} 
anthelmintic, antidiabetic, diuretic, analgesic, antitumor, astringent and anti-asthmatic properties (Neelam et al., 2015; Rana \& Avijit, 2012; Shrestha \& Dhillion, 2003).

Netrokona district is located in between $24^{\circ} 34^{\prime}$ and $25^{\circ} 12^{\prime}$ north latitudes and in between $90^{\circ} 00^{\prime}$ and $91^{\circ} 07^{\prime}$ east longitudes. It is bounded by the Meghalaya state of India on the north, Kishoreganj district on the south, Sunamganj district on the east and Mymensingh district on the west. Garo, Hajong, Hodi and Banai are the minor indigenous communities among the population of Netrokona district (BBS, 2007). Being a peripheral district most of the indigenous people are on the verge of disappearance because of decline in population, loss in tribal habitat, or because of merging with the mainstream Bengalispeaking population. Madan and Kendua Upozilla of Netrokona district is well known for its diverse inhabitants and cultural practice. Since ethnomedicinal surveys of various tribes and folk medicinal practitioners are still at an early stage in Bangladesh, the primary objective of the present study was to document the hitherto unreported traditional medicinal practices of $B$. monosperma in the villages of Madan and Kendua Upozilla of Netrokona district. Till to date no document came up with the information on ethnomedicinal use of $B$. monosperma in Netrokona district of Bangladesh. Thus, the main objectives of the present research aims to prepare a comprehensive documentation of indigenous knowledge on the utilization of $B$. monosperma by local inhabitants and Garo and Hazong ethnic communities, followed by determination of phytochemical composition, cytotoxicity and antioxidant potential of different plant parts.

\section{MATERIALS AND METHODS}

Ethnobotanical study and survey: Extensive field trips were conducted for ethnobotanical survey using a semi-structured questionnaire prepared following Martin (2008). Ten kavirajes of two upozilla (Madan and Kendua) of Netrokona District with the age ranging from 50 to 60 years were interviewed individually and they pointed out the use of B. monosperma to treat different ailments.

Collection and Identification: Samples of root, stem, leaf, flower and seed of $B$. monosperma plant were collected separately from Netrokona district and deposited in Plant Systematics and Biodiversity laboratory of Jahangirnagar University for preliminary identification. Finally the identification of the plant specimens were verified and authenticated by the Bangladesh National Herbarium (DACB), Mirpur, Dhaka, Bangladesh. The voucher specimen (accession no- DACB-39193) has been deposited in DACB for further reference.

Preparation of crude extracts: The collected plant parts were separately sun-dried followed by drying in a hot air oven (Gallenkamp) at reduced temperature $\left(<50^{\circ} \mathrm{C}\right)$. About $200 \mathrm{~g}$ powder of each plant parts was digested with $1000 \mathrm{ml}$ of methanol for three days accompanying with occasional shaking and stirring. The whole mixtures was filtrated by a piece of clean, white cotton material. The extract was concentrated at $45^{\circ} \mathrm{C}$ under reduced pressure using a rotary evaporator.

Phytochemical screening: The crude methanolic extracts of flower, leaves and stem were subjected to different qualitative tests to find out the presence of chemical 
constituents using standard procedure (Evans, 1989; Sofowara, 1993; Ghani, 1998 and Dev, 2002). Molisch's and Fehling's reagents were used to investigate the presence of carbohydrates and reducing sugar, respectively. Hagger's reagent, Wagner's reagent, Mayer's reagent and Dragendroff's reagents were used to test the presence of alkaloids while $\mathrm{FeCl}_{3}$ test and Keller Killiani's test (Khandelwal, 2008) were carried out for glycosides and cardenolides, respectively. Borntrager's test (Houghton \& Rahman, 1998) was conducted to know the presence of anthraquinone glycosides; Lead acetate, Alkali, $\mathrm{FeCl}_{3}$ and Conc. $\mathrm{H}_{2} \mathrm{SO}_{4}$ were used for the detection of flavonoids. $\mathrm{FeCl}_{3}$, ammonia and lead acetate were used to test the presence of phenolic compounds. Concentrated $\mathrm{H}_{2} \mathrm{SO}_{4}$ was used to detect terpenoids whereas acetic anhydride was used to check the presence of triterpene. The presence of phytosterols/steroids was indicated by the Salkowski's test (Kokate et al., 2008) while the presence of saponins was confirmed by foam test (Kokate et al., 2008).

Determination of antioxidant activity: The antioxidant activities of the extracts were measured on the basis of the scavenging activity of the stable 1,1-diphenyl-2picrylhydrazyl (DPPH) free radical following the method described by Blois (1958) and Aoshima et al. (2004). $150 \mu \mathrm{l}$ DPPH solution was added to $3 \mathrm{ml}$ methanol and absorbance was taken immediately at $517 \mathrm{~nm}$ for control reading. $50 \mu 1$ of various concentrations of different fractions as well as standard compound (ascorbic acid) were taken and the volume was made uniformly to $150 \mu 1$ using methanol. Each of the samples was then further diluted with methanol up to $3 \mathrm{ml}$ and to each $150 \mathrm{ml}$ DPPH was added. Finally, absorbance at $517 \mathrm{~nm}$ was determined after $30 \mathrm{~min}$. and the percent inhibition activity was calculated as

DPPH free radical scavenging activity $(\%)=\frac{\text { control absorption }- \text { corrected sample absorption }}{\text { control absorption }} \times 100$

Brine shrimp lethality bioassay: The lethality of a test sample in a simple zoological organism such as the shrimp (Artemia salina) has been utilized by Meyer et al. (1982) through the Brine Shrimp Cytotoxicity Test (BSCT). It has been well utilized to screen and fractionation of physiologically active plant extracts as well. This bioassay is indicative of cytotoxicity and a wide range of pharmacological activity of natural products. Brine shrimps (Artemia salina) lethality bioassay was followed by Meyer et al. (1982).

\section{RESULTS AND DISCUSSION}

Folk medicine is a traditional form of medicinal practice in Bangladesh, which is practiced by practitioners existing both among the mainstream Bengali-speaking population as well as among the various indigenous communities of Bangladesh. The mainstay of the folk medicinal formulations consist of medicinal plants, which are used directly or in the form of decoctions, juice, pastes and are administered either orally or topically, depending upon the ailments treated. The findings from the ethnomedicinal survey among the local inhabitants including a few ethnic communities (Garo and 
Hazong) of Madan and Kendua Upozilla of Netrokona district have been presented in Table 1.

Table 1. Ethnomedicinal information on Butea monosperma obtained from Madan and Kendua Upozilla of Netrokona district.

\begin{tabular}{|c|c|c|c|c|c|c|}
\hline $\begin{array}{l}\text { Netrokona } \\
\text { District }\end{array}$ & Village & $\begin{array}{c}\text { Name of } \\
\text { practitioner }\end{array}$ & $\begin{array}{c}\text { Age } \\
\text { (years) }\end{array}$ & Ailment & $\begin{array}{l}\text { Parts } \\
\text { used }\end{array}$ & Process of use \\
\hline \multirow{5}{*}{$\begin{array}{l}\text { Madan } \\
\text { Upozilla }\end{array}$} & Porashkhila & Mahindro & 65 & $\begin{array}{l}\text { Stomach } \\
\text { disorder, } \\
\text { cough and } \\
\text { cold }\end{array}$ & Petiole & $\begin{array}{l}8-10 \text { leaf petiole is chewed } \\
\text { and juice is taken in empty } \\
\text { stomach. }\end{array}$ \\
\hline & Gobindrosri & $\begin{array}{l}\text { Fahima } \\
\text { Akter }\end{array}$ & 53 & Goiter & Stem & $\begin{array}{l}\text { Necessary amount of tender } \\
\text { stem is smashed with lime } \\
\text { stone and the paste is applied } \\
\text { on goiter developed area. }\end{array}$ \\
\hline & Gonganagar & $\begin{array}{l}\text { Nasrin } \\
\text { Akter }\end{array}$ & 56 & Snake bite & Root & $\begin{array}{l}\text { Two teaspoonful of root } \\
\text { powder and a teaspoon of } \\
\text { honey mixed with water and } \\
\text { drink as an antidote for snake } \\
\text { bite. }\end{array}$ \\
\hline & Bagjan & Al Amin & 50 & Diabetes & Leaf & $\begin{array}{l}\text { Dried leaf powder, about two } \\
\text { spoonful per day over a } \\
\text { period of months is drunk } \\
\text { mixed with a cup of water to } \\
\text { cure diabetes. }\end{array}$ \\
\hline & Kapasatia & $\begin{array}{l}\text { Prodip } \\
\text { Chandro } \\
\text { Sutrodhar }\end{array}$ & 58 & $\begin{array}{c}\text { Painful } \\
\text { menstruation }\end{array}$ & $\begin{array}{l}\text { Leaf } \\
\text { and } \\
\text { Flower }\end{array}$ & $\begin{array}{l}\text { Fresh leaf extract about three } \\
\text { to four teaspoon mixed with } \\
1 / 4 \text { teaspoon of fresh flower } \\
\text { extract, is drunk at night for } \\
\text { two to three months to } \\
\text { checks irregular bleeding of } \\
\text { menstruation. }\end{array}$ \\
\hline \multirow{5}{*}{$\begin{array}{l}\text { Kendua } \\
\text { Upozilla }\end{array}$} & Pubati & Rupok & 50 & $\begin{array}{c}\text { Body } \\
\text { swellings }\end{array}$ & Bark & $\begin{array}{l}\text { To cure body swelling, paste } \\
\text { of stem and bark together is } \\
\text { applied on twice a day. }\end{array}$ \\
\hline & Dauki & $\begin{array}{l}\text { Chinmoy } \\
\text { Dhor }\end{array}$ & 55 & $\begin{array}{l}\text { Intestinal } \\
\text { worms }\end{array}$ & Seeds & $\begin{array}{l}\text { Two to three seeds powdered } \\
\text { and consumed by children on } \\
\text { a remedy against intestinal } \\
\text { worms }\end{array}$ \\
\hline & Dipara & $\begin{array}{l}\text { Arup } \\
\text { Kumar }\end{array}$ & 65 & $\begin{array}{l}\text { Kidney } \\
\text { stone }\end{array}$ & Seeds & $\begin{array}{l}\text { A little amount (unspecified) } \\
\text { of seeds are crushed in milk } \\
\text { and this mixture about two } \\
\text { spoons is taken orally. }\end{array}$ \\
\hline & Alampur & Kuddus Ali & 60 & Leucorrhoea & Flower & $\begin{array}{l}\text { 7-8 fresh flower is soaked in } \\
\text { water over night and a cup of } \\
\text { this infusion is drunk every } \\
\text { morning. }\end{array}$ \\
\hline & Sandikona & Majed Ali & 62 & $\begin{array}{l}\text { Chronic } \\
\text { fever }\end{array}$ & Flower & $\begin{array}{l}\text { 5-6 fresh flowers are crushed } \\
\text { in milk and a teaspoon of } \\
\text { sugar is added. Three to four } \\
\text { spoons drunk per day over a } \\
\text { period of a month. }\end{array}$ \\
\hline
\end{tabular}


The Kavirajes were explained properly for providing the information that was wanted, the purpose for obtaining this information, and told that the survey results may be disseminated both nationally and internationally as they prefer to keep their knowledge and formulations, inherited from their forefathers, between themselves.

The survey revealed that stem and flower of B. monosperma were the most used parts for medicinal purposes in Netrokona district (Fig. 1). The next popular parts of the plant used were leaves and seeds, where each of them scored $17 \%$ of the total usage. Petiole and root of the plant showed least usage (8\%). Interestingly, the use of B. monoperma root in medicinal purpose was not well recorded. In Bangladesh, this may be the first information on the medicinal use of B. monosperma root (Table 1). Patil et al. (2006) reported on the similar use of this plant from India. However, the findings on the usage of leaf, stem, flower and seeds of $B$. monosperma plant to treat different diseases of human are corroborated with that of Sharma \& Deshwal (2011), Kirtikar \& Basu (1935) and Kumar \& Samanta (2012).

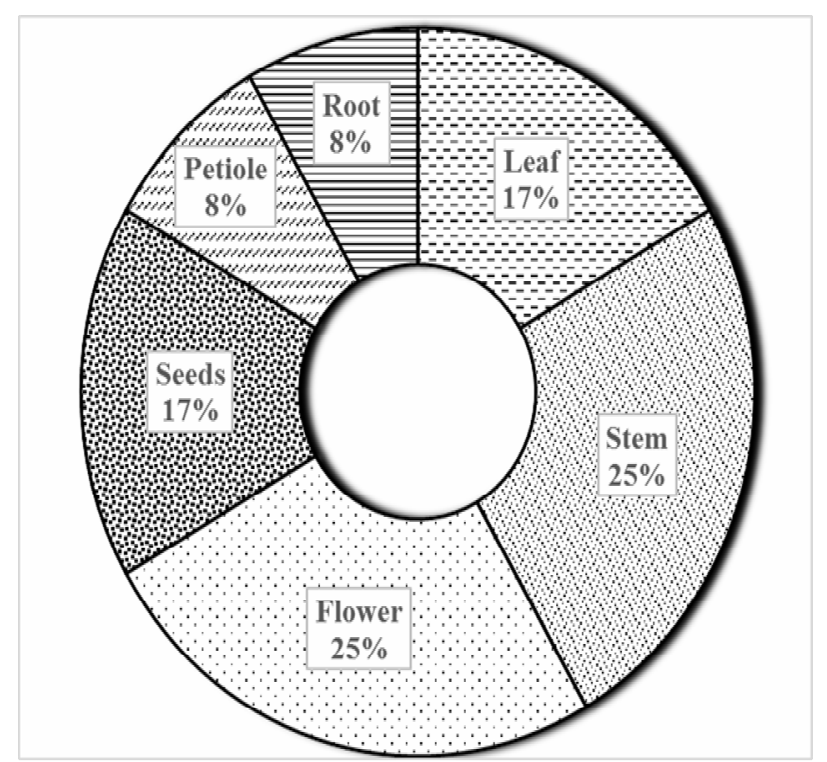

Fig. 1. Comparison among the usage of different parts of $B$. monosperma plant by the Kavirajes of Madan and Kendua upozilla of Netrokona district

The results of phytochemical screening of flower, leaves and stem of $B$. monosperma as presented in Table 2 showed the inconsistent presence of major secondary metabolites, viz. carbohydrates, glycosides, cardiac glycoside, flovonoids, phenolics tannins and terpenoids. 
Table 2. Qualitative chemical examination of flower leaves and stem extracts of $B$. monosperma

\begin{tabular}{|c|c|c|c|c|c|}
\hline \multirow{2}{*}{$\begin{array}{l}\text { S1 } \\
\text { no. }\end{array}$} & \multirow[t]{2}{*}{ Phytochemicals } & \multirow{2}{*}{$\begin{array}{l}\text { Reagents and tests to detect } \\
\text { phytochemicals }\end{array}$} & \multicolumn{3}{|c|}{ Plant samples } \\
\hline & & & Flower & Leaves & Stem \\
\hline \multirow[t]{2}{*}{01.} & Carbohydrates & Molish's reagent & $(++)$ & $(++)$ & $(++)$ \\
\hline & & Fehling reagent & $(++)$ & $(++)$ & $(++)$ \\
\hline \multirow[t]{5}{*}{02.} & Alkaloids & Hagger's reagent & $(-)$ & $(-)$ & $(-)$ \\
\hline & & Wagner's reagent & $(-)$ & $(-)$ & $(-)$ \\
\hline & & Mayer's reagent & $(-)$ & $(+)$ & $(+)$ \\
\hline & & Draggendrof's reagent & $(+)$ & $(+)$ & $(+)$ \\
\hline & & Tannic acid solution (10\%) & $(-)$ & $(-)$ & $(-)$ \\
\hline \multirow[t]{3}{*}{03.} & Glycosides & $\mathrm{FeCl}_{3}$ glycoside test & $(+++)$ & $(++)$ & $(++)$ \\
\hline & a. Cardiac glycosides & Keller Killiani's & $(+)$ & $(+)$ & $(+)$ \\
\hline & $\begin{array}{l}\text { b. Anthraquinone } \\
\text { glycosides }\end{array}$ & Borntrager's & $(+)$ & $(+)$ & $(-)$ \\
\hline \multirow[t]{4}{*}{04.} & Flavonoids & Lead acetate & $(+++)$ & $(++)$ & $(++)$ \\
\hline & & Alkali & $(+++)$ & $(++)$ & $(++)$ \\
\hline & & Conc. $\mathrm{H}_{2} \mathrm{SO}_{4}$ & $(++)$ & $(+)$ & $(+)$ \\
\hline & & $\mathrm{FeCl}_{3}$ & $(+++)$ & $(++)$ & $(++)$ \\
\hline \multirow[t]{2}{*}{05.} & $\begin{array}{l}\text { Terpenoids } \\
\text { a. Terpene }\end{array}$ & $\mathrm{CHCl}_{3}+$ Conc. $\mathrm{H}_{2} \mathrm{SO}_{4}$ & $(++)$ & $(+)$ & $(+)$ \\
\hline & b. Triterpene & $\mathrm{CHCl}_{3}+$ Acetic anhydride & $(+)$ & $(+)$ & $(+)$ \\
\hline 06. & Steroids & Salkowski test & $(+)$ & $(+)$ & $(+)$ \\
\hline \multirow[t]{3}{*}{07.} & Phenols & $\mathrm{FeCl}_{3}$ & $(+)$ & $(+)$ & $(+)$ \\
\hline & & Ammonia & $(-)$ & $(-)$ & $(-)$ \\
\hline & & Lead acetate & $(+)$ & $(+)$ & $(+)$ \\
\hline 08. & Saponins & Foam test & $(+)$ & $(+)$ & $(+)$ \\
\hline
\end{tabular}

NB: $+++=$ Strong,$++=$ Moderate,$+=$ Weak,$-=$ Negative

Crude methanolic flower extract of $B$. monosperma showed strong presence of flavonoids and glycosides, moderate presence of carbohydrates, phenols, tannins and very weak presence of terpenoids and saponins. These results are corroborated with the findings of Ahmed et al. (2011). Stem and leaves showed moderate presence of carbohydrates, glycosides, flavonoids, phenols and tannins. Alkaloids, terpenoids and saponins were found to be very feebly present in them (Rajput et al., 2011). In the present experiment different plant parts of $B$. monosperma showed varying degree of cytotoxicity. In Brine Shrimp Lethality bioassay, the crude methanolic extract of leaves of $B$. monosperma showed $\mathrm{LC}_{50}$ value $427.88 \mu \mathrm{g} / \mathrm{ml}$ after 6 hours followed by the $\mathrm{LC}_{50}$ values $691.70 \mu \mathrm{g} / \mathrm{ml}$ for flowers and $809.57 \mu \mathrm{g} / \mathrm{ml}$ for stem extracts. With the progression of hours the cytotoxicity gradually increased. After 12 hours, the $\mathrm{LC}_{50}$ values for leaves, flowers and stem were $148.25 \mu \mathrm{g} / \mathrm{ml}, 223.03 \mu \mathrm{g} / \mathrm{ml}$ and $463.25 \mu \mathrm{g} / \mathrm{ml}$ respectively. However, after 24 hours the $\mathrm{LC}_{50}$ values for flower, leaves and stem were $94.44 \mu \mathrm{g} / \mathrm{ml}, 26.06 \mu \mathrm{g} / \mathrm{ml}$ and $113.24 \mu \mathrm{g} / \mathrm{ml}$ respectively (Table 3 ). Vincristine sulphate was considered as the standard compound to assess the cytotoxicity which showed $\mathrm{LC}_{50}$ values $0.069 \mu \mathrm{g} / \mathrm{ml}, 0.031 \mu \mathrm{g} / \mathrm{ml}$ 
and $0.009 \mu \mathrm{g} / \mathrm{ml}$ after 6 hours, 12 hours and 24 hours respectively. Among the plant parts, leaves extract showed greater cytotoxicity compared to flower and stem extracts. Kumar et al. (2009) reported on $\mathrm{LC}_{50}$ value $502.41 \mu \mathrm{g} / \mathrm{ml}$ for Butea frondosa leaf extracts. Sehrawat \& Sultana (2006) reported on the application of leaf extract of B. monosperma in treatment against 2-AAF induced hepatic toxicity and hyperproliferation.

Table 3. Cytotoxicity assay of crude methanolic extract of flower, leaves and stem of $B$. monosperma

\begin{tabular}{|c|c|c|c|c|c|c|c|c|c|}
\hline \multirow[t]{2}{*}{ Duration } & \multirow[t]{2}{*}{$\begin{array}{l}\text { Conc. } \\
(\mu \mathrm{g} / \mathrm{ml})\end{array}$} & \multicolumn{2}{|c|}{ Flower } & \multicolumn{2}{|c|}{ Leaves } & \multicolumn{2}{|c|}{ Stem } & \multicolumn{2}{|c|}{$\begin{array}{l}\text { Vincristine } \\
\text { sulphate }\end{array}$} \\
\hline & & $\begin{array}{c}\text { Mortality } \\
(\%)\end{array}$ & $\begin{array}{c}\mathrm{LC}_{50} \\
(\mu \mathrm{g} / \mathrm{ml})\end{array}$ & $\begin{array}{c}\text { Mortality } \\
(\%)\end{array}$ & $\begin{array}{c}\mathrm{LC}_{50} \\
(\mu \mathrm{g} / \mathrm{ml})\end{array}$ & $\begin{array}{c}\text { Mortality } \\
(\%)\end{array}$ & $\begin{array}{c}\mathrm{LC}_{50} \\
(\mu \mathrm{g} / \mathrm{ml})\end{array}$ & $\begin{array}{c}\text { Conc. } \\
(\mu \mathrm{g} / \mathrm{ml})\end{array}$ & $\begin{array}{l}\mathrm{LC}_{50} \\
(\mu \mathrm{g} / \mathrm{ml})\end{array}$ \\
\hline \multirow{9}{*}{6 hours } & Control & 0 & \multirow{9}{*}{691.70} & 0 & \multirow{9}{*}{427.88} & 0 & & Control & \multirow{9}{*}{0.0699} \\
\hline & 0 & 0 & & 0 & & 0 & & 0 & \\
\hline & 10 & 0 & & 0 & & 0 & & 0.06 & \\
\hline & 20 & 0 & & 0 & & 0 & & 0.125 & \\
\hline & 40 & 0 & & 0 & & 0 & 809.57 & 0.25 & \\
\hline & 80 & 0 & & 0 & & 0 & & 0.5 & \\
\hline & 160 & 10 & & 20 & & 10 & & 1 & \\
\hline & 200 & 20 & & 25 & & 15 & & 5 & \\
\hline & 400 & 30 & & 30 & & 20 & & 10 & \\
\hline \multirow{9}{*}{12 hours } & Control & 0 & \multirow{9}{*}{ 223.03 } & 0 & \multirow{9}{*}{148.25} & 0 & & Control & \multirow{9}{*}{0.031} \\
\hline & 0 & 0 & & 0 & & 0 & & 0 & \\
\hline & 10 & 10 & & 10 & & 0 & & 0.06 & \\
\hline & 20 & 15 & & 15 & & 10 & & 0.125 & \\
\hline & 40 & 25 & & 25 & & 15 & 463.25 & 0.25 & \\
\hline & 80 & 25 & & 25 & & 20 & & 0.5 & \\
\hline & 160 & 45 & & 55 & & 25 & & 1 & \\
\hline & 200 & 65 & & 55 & & 50 & & 5 & \\
\hline & 400 & 90 & & 80 & & 70 & & 10 & \\
\hline \multirow{9}{*}{24 hours } & Control & 0 & \multirow{9}{*}{94.44} & 0 & \multirow{9}{*}{26.06} & 0 & & Control & \multirow{9}{*}{0.009} \\
\hline & 0 & 0 & & 0 & & 0 & & 0 & \\
\hline & 10 & 35 & & 30 & & 15 & & 0.06 & \\
\hline & 20 & 40 & & 45 & & 20 & & 0.125 & \\
\hline & 40 & 45 & & 45 & & 25 & 113.24 & 0.25 & \\
\hline & 80 & 60 & & 55 & & 50 & & 0.5 & \\
\hline & 160 & 85 & & 80 & & 70 & & 1 & \\
\hline & 200 & 95 & & 90 & & 85 & & 5 & \\
\hline & 400 & 100 & & 100 & & 100 & & 10 & \\
\hline
\end{tabular}

Note: Vincristine sulphate used as a positive control.

Considering the above facts plant samples may be regarded as moderate to poor cytotoxic. Panda et al. (2009) isolated a stigmasterol from the bark of B. monosperma and evaluated for its thyroid hormone and glucose regulatory efficacy in mice. Rekha (2011) reported that the ethanolic extract of $B$. monosperma showed significant anti-cancer 
activity in the tested animal models. However, the present findings may be the first comparative cytotoxicity profile for different parts of $B$. monosperma plant.

The antioxidant activities of flower, leaves and stem extracts were measured as percentage of DPPH free radical scavenging activity and have been presented in Fig. 2. The methanolic extract of the flower of $B$. monosperma showed maximum antioxidant or DPPH free radical scavenging activity $(73.49 \%)$ followed by scavenging activities of stem $(58.58 \%)$ and leaves $(48.17 \%)$ respectively. Ascorbic acid, the reference compound to measure antioxidant potential of the samples, showed $87.07 \%$ DPPH free radical scavenging activity. Relatively higher concentrations of the samples showed higher antioxidant activity compared to low and moderate concentrations of the fractions. Present results on antioxidant potential of different parts of $B$. monosperma corroborates with the findings Edwin et al., 2009; Lavhale \& Mishra, 2007 and Sharma \& Garg, 2009.

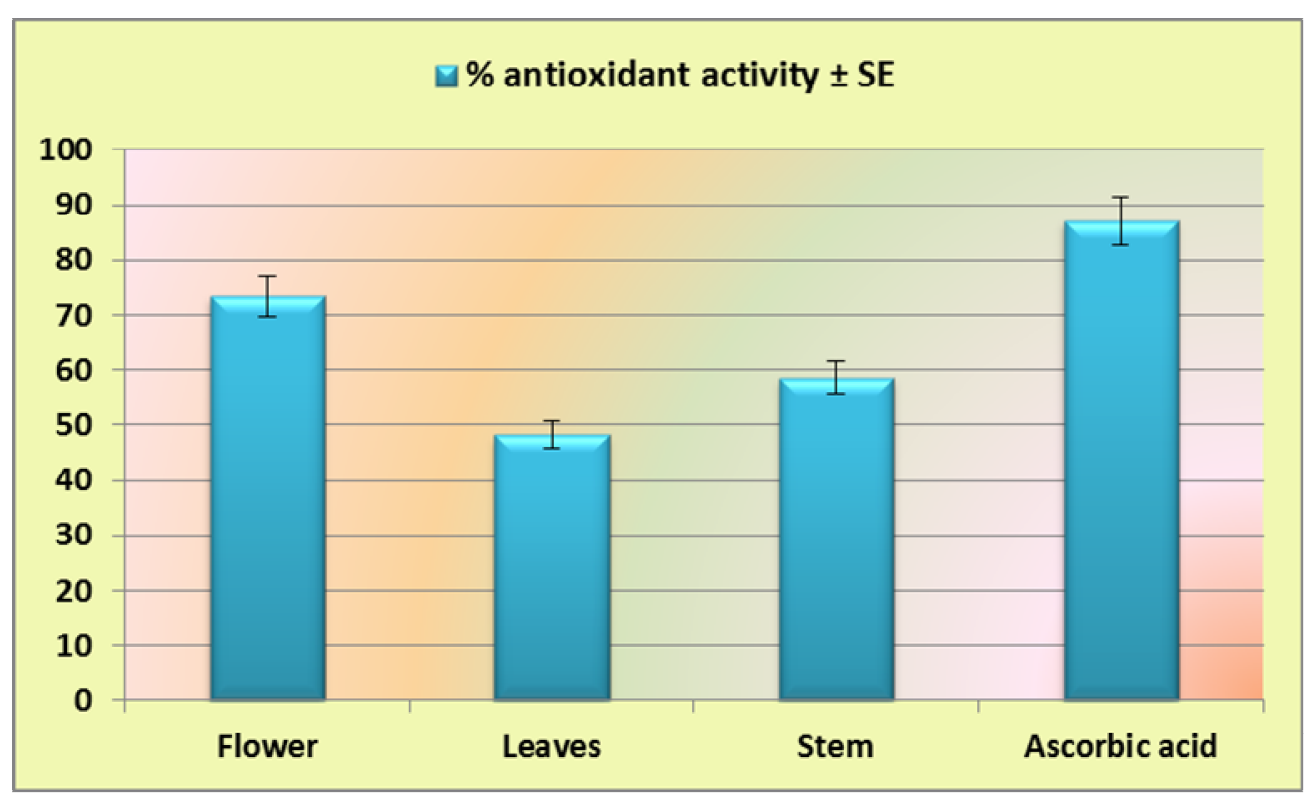

Fig. 2. DPPH free radical scavenging activity of methanolic crude extracts $(100 \mu \mathrm{g} / \mathrm{ml}) \mathrm{of}$ flower, leaves and stems of $B$. monosperma

The total phenolic content (TPC) was determined in comparison with standard Gallic acid and the results were expressed in terms of $\mathrm{mg}$ Gallic acid equivalent (GAE)/ $100 \mathrm{~g}$ dry sample. Among the B. monosperma samples, maximum amount of phenolic content was recorded as $85.88 \mathrm{mg} / 100 \mathrm{~g}$ in flower extract followed by $64.84 \mathrm{mg} / 100 \mathrm{~g}$ in stem extract and $60.48 \mathrm{mg} / 100 \mathrm{~g}$ in leaves extract (Fig. 3). These variations were found statistically significant when analyzed by DMRT at $5 \%$ level of significance. Salar \& Seasotiya (2011) reported that antioxidant properties of bark of $B$. monosperma extracted according to increasing and decreasing solvent polarity. According to them significant variations 
were found in total phenolic content and antioxidant activity depending on the solvent and method of extraction.

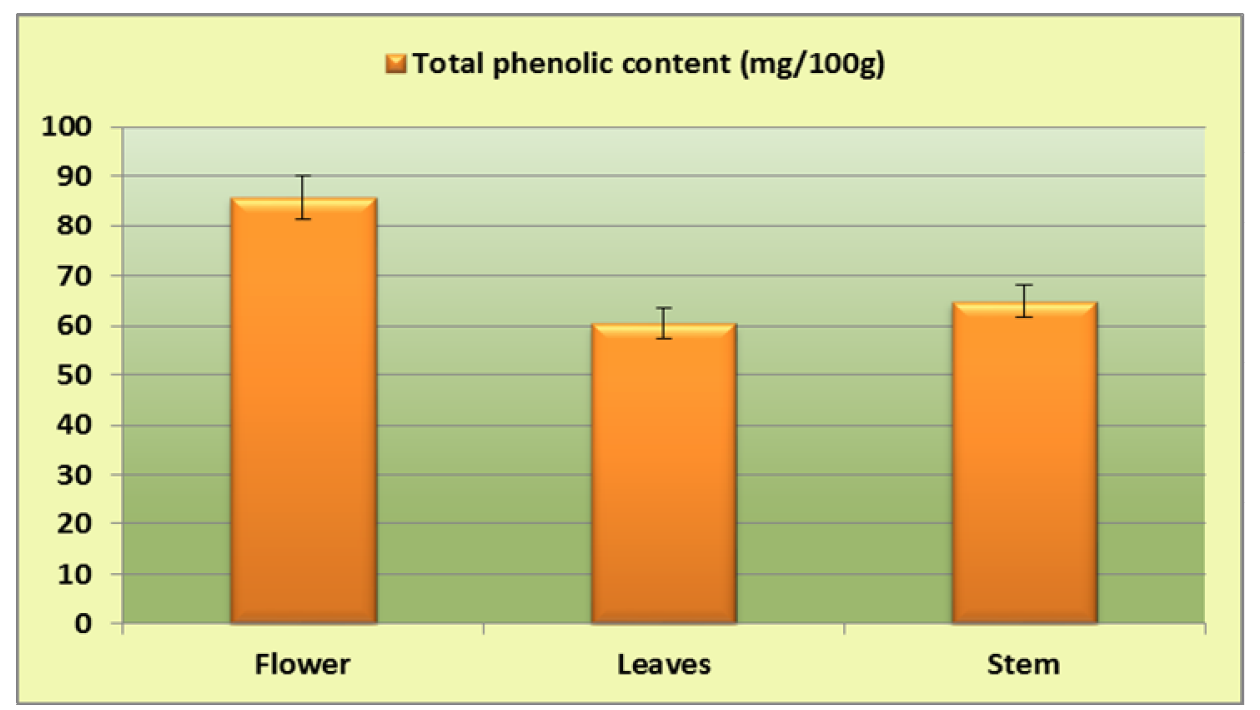

Fig. 3. Total phenolic content (TPC) of methanolic crude extracts (GAE/100 g) of flower, leaves and stems of $B$. monosperma

Phenolic compounds are widely distributed in plants (Li et al., 2006), which have gained great attention, due to their antioxidant activities and free radical-scavenging abilities, which potentially have beneficial implications for human health (Govindarajan et al., 2007). In the present investigation, other than phenols, stem and leaves extract showed the presence of sterols, steroids, terpenoids and glycosides which are known to have ameliorative effect on human health. Besides, COX-2, an enzyme responsible for inflammation and pain in human being are inhibited by aromatic-5-membered ring heterocycles. The COX-2 inhibitors have analgesic, antipyretic and inflammatory activity comparable to NSAIDs and are used therapeutically in acute pain, and primary dysmenorrhea (Rao et al., 2010). Moreover, epidemiological studies and associated metaanalyses strongly suggested that consumption of diets rich in plant polyphenols offered some protection against development of cancers, cardiovascular diseases, diabetes, osteoporosis and neurodegenerative diseases (Pandey \& Rizvi, 2009). Thus, the results of the present study may be a proof of a scientific basis for the use of $B$. monosperma in traditional medicine and further studies are needed to focus on isolation of novel bioactive compounds from different parts of B. monosperma following extensive phytochemical and pharmacological studies.

Acknowledgement: The authors would like to express their gratitude to University Grants Commission (UGC) for providing the research grant and to the Department of Botany, Jahangirnagar University for providing the research facilities to conduct the research. 


\section{REFERENCES}

Ahmed, F.A., Kim, S.Y., Kurimoto, S.I., Sasaki, H., Shibata, H., Kashiwada, Y. and Takaishi, Y. 2011. Biflavonoids from flowers of Butea monosperma (Lam.) Taub. Heterocycles 83(9): 2079 - 2089.

BBS, 2007. Cultural survey report of upazilas of Netrokona District. (http://en.banglapedia.org/index.php?title=Netrokona_District)

Edwin, J.E., Nalwaya N., Meena M., Jain A. and Edwin S. 2009. Determination of rutin content and antioxidant activity of extracts of Butea monosperma flowers extracted using various extraction methods. Pharmacognosy J. 1:126-9.

Govindarajan, R., Vijayakumar, M., Rao, C.V., Shirwaikar, A., Kumar, S., Rawat, A.K.S. and Pushpangadan, P. 2007. Anti-inflammatory and antioxidant activities of Desmodium gangeticum fractions in carrageenan-induced inflamed rats. Phytotherapy Res. 21:975979.

Gurib-Fakim, A. 2006. Medicinal plants: Traditions of yesterday and drugs of tomorrow. Mol. Aspects Med. 27: 1- 93.

Houghton, P. and Rahman, A. 1998. Laboratory handbook for the fractionation of natural extracts, $1^{\text {st }}$ edn. Pubs. by Chapman and Hall, London. pp. 159-160.

Khandelwal, K.R. 2008. Practical pharmacognosy, 19 $^{\text {th }}$ edn. Pubs. by Nirali Prakashan. Pune, India. pp. 152.

Kirtikar, K.R. and Basu, B.D. 1935. Indian medicinal plants, ( $2^{\text {nd }}$ edn. $)$, Vol-I. Allahabad, India, 785-788.

Kokate, C.K., Purohit, A.P. and Gokhale, S.D. 2008. Pharmacognosy, $2^{\text {nd }}$ edn. Pubs. by Nirali Prakashan. Pune, India. pp. 597.

Kornkanok, I., Prapapan, T., Kanchanaporn, C, Thitaree, Y. and Warawit, T. 2003. Screening for acetylcholinesterase inhibitory activity in plants used in Thai traditional rejuvenating and neurotonic remedies. J. Ethnopharmacol. 89: 261-164.

Kumar, A. and Samanta, K. 2012. A multipurpose medicinal tree Butea monosperma. Intl. J. Drug Disc. Herb. Res. 2(2): 436-441.

Kumar, A., Rana, R., Mahour, K. and Vihan, V.S. 2009. Cytotoxic activity of indigenous medicinal plants based on brine shrimp lethality test. Indian Veter. J. 86(6): 558-559.

Lavhale, M.S. and Mishra, S.H. 2007. Evaluation of free radical scavenging activity of Butea monosperma Lam. Ind. J. Exp. Biol. 45:376-84.

Li, B.B., Smith A.B. and Hossain M.M. 2006. Extraction of phenolics from citrus peels: II. Enzyme-assisted extraction method. Sep. Purif. Technol. 48: 189-96.

Martin, G.J. 2008. Ethnobotany: A methods manual. Chapman and Hall, London, pp. 110-112.

Murmu, M. 2009. Adivasi Anneshon. Pubs. by Nawroze Kitabistan, Dhaka, Bangladesh.

Neelam, Dwivedi, K.N. and Ram B. 2015. Palash (Butea monosperma Lam. Kuntze.): A Review. Int. J. Ayu. Pharm. Chem. 2(3): 95-104.

Pandey, K.B. and Rizvi, S.I. 2009. Plant polyphenols as dietary antioxidants in human health and disease. Oxid. Med. Cell. Longev. 2(5): 270-278.

Patil, M.V., Pawar, S. and Patil, D.A. 2006. Ethnobotany of Butea monosperma (Lam.) Kuntze in North Maharastra, India. Nat. Prod. Rad. 5(4):323-325.

Rajput, A., Pal, S.C. and Patil, B. 2011. Phytochemical screening, antibacterial activity and physicochemical evaluation of leaves of Butea monosperma. Int. J. Pharm. Pharm. Sci. 3(3): 189-191.

Rao, P.P.N., Kabir, S.N. and Mohamed, T. 2010. Nonsteroidal anti-inflammatory drugs (NSAIDs): progress in small molecule drug development. Pharmaceuticals 3: 1530-1549.

Rana, F. and Avijit, M. 2012. Review on Butea monosperma. Intl. J. Res. Pharmacy Chem. 2(4): 1035-1039. 
Rashid, M.A., Haque, M.R., Sikder, M.A.A., Chowdhury, A.A., Rahman, M.S. and Hasan, C.M. 2014. Review on chemistry and bioactivities of secondary metabolites from some medicinal plants and microbes of Bangladesh. Bangladesh Pharm. J. 17(1): 63-79.

Rekha, J.B. and Jayakar, B. 2011. Anti- cancer activity of ethanolic extract of leaves of Butea monosperma (Lam.) Taub. Curr. Pharma. Res. 1(2): 106-110.

Salar, R.K. and Seasotiya, L. 2011. Free radical scavenging activity, phenolic contents and phytochemical evaluation of different extracts of stem bark of Butea monosperma (Lam.) Kuntze. Frontiers in Life Science 5(3\&4): 107-116.

Sehrawat, A. and Sultana, S. 2006. Chemoprevention by Butea monosperma of hepatic carcinogenesis and oxidative damage in male wistar rats. Asian Pac. J. Cancer Prev. 7(1): 140-8.

Panda S., Jafri M., Kar A. and Meheta B.K. 2009. Thyroid inhibitory, antiperoxidative and hypoglycemic effects of stigmasterol isolated from Butea monosperma. Fitoterapia 80: 123-126.

Sharma, A.K. and Deshwal, N. 2011. An Overview: On Phytochemical and Pharmacological Studies of Butea Monosperma. Intl J. Pharm. Tech. Res. 3(2): 864-871.

Sharma, N. and Garg, V. 2009. Antidiabetic and antioxidant potential of ethanolic extract of Butea monosperma leaves in alloxan-induced diabetic mice. Indian J. Biochem. Biophys. 46:99105.

Shrestha, P.M. and Dhillion, S.S. 2003. Medicinal plants diversity and use in the highlands of Dolakha district. Nepal J. Ethnopharmacol. 86(1):81-96.

Tomoko, N., Takashi, A., Hiromu, T., Yuka, I., Hiroko, M., Munekazu, I., Fujio, A. and Kazuhito, W. 2002. Antibacterial activity of extracts prepared from tropical and subtropical plants on methicillin resistant Staphylococcus aureus. J. Health Sci. 48: 273-76. 